\title{
Digital control strategy for SPWM MPPT of PV system with three-phase NPC three-level converter
}

\author{
Mahmoud Aref ${ }^{1}$, Ismaiel Ahmed ${ }^{2}$, Vladislav Oboskalov ${ }^{3}$ \\ ${ }^{1,2,3}$ Ural Power Engineering Institute, Ural Federal University, Russia \\ ${ }^{1}$ Department of Electrical Engineering, Assiut University, Egypt
}

\begin{tabular}{|c|c|}
\hline Article Info & ABSTRACT \\
\hline Article history: & \multirow{12}{*}{$\begin{array}{l}\text { This paper is aimed at investigating MPPT of PV system controlled by } \\
\text { SPWM which is generated by comparing sinusoidal wave with variable } \\
\text { frequency sawtooth wave. Perturb and Observe (P\&O) method is used for } \\
\text { MPPT control of PV system. NPC three-phase three-level converter with } \\
\text { LCL filter is designed to produce output voltage with minimum Total } \\
\text { Harmonic Distortion (THD) and high efficiency. The simple and fast method } \\
\text { to get MPP of PV system with variable irradiation is digital control where the } \\
\text { maximum power point is obtained from look-up table for the values of } \\
\text { optimum voltage that achieve the maximum power for each irradiance value } \\
\text { is used for digital control signal in microcontroller. The output voltage } \\
\text { harmonic of multi-level three-phase inverter is controlled using SPWM } \\
\text { control. THD of output voltage of multi-level three-phase inverter is } 22 \% \text { of } \\
\text { stand-alone and grid-connected PV system. Small rate LCL filter is used to } \\
\text { limit voltage harmonics within medium and low voltage limits } 5 \% \text { ). } \\
\text { THD output voltage of LCL filter is } 4.9 \% \text { and } 3.51 \% \text { of stand-alone and grid- } \\
\text { connected PV system respectively. }\end{array}$} \\
\hline Received Nov 4, 2019 & \\
\hline Revised Feb 6, 2020 & \\
\hline Accepted Feb 27, 2020 & \\
\hline & \\
\hline Keywords: & \\
\hline Grid & \\
\hline Inverter & \\
\hline LCL filter & \\
\hline Multi-level & \\
\hline & \\
\hline Stand-alone & \\
\hline
\end{tabular}

Copyright $@ 2020$ Institute of Advanced Engineering and Science. All rights reserved.

\section{Corresponding Author:}

Mahmoud Aref,

Ural power Engineering institute,

Ural Federal Universit, Yekaterinburg, Russia.

Email: mahmoud2006aref@gmail.com

\section{INTRODUCTION}

The penetration level of photovoltaic (PV) generated energy into the grid system was increased in worldwide. This increased penetration level offers unique challenges to systems operators. Improving reliability so as to reduce replacement cost during the life of the system is one of significant challenges [1]. Usually PV plant consists of 3 main parts: large number of PV modules which are combined together to feed inverters. The inverters then are connected to low frequency transformer (medium voltage electric grid) [2].

Converters are main part in PV system in order to integrate with AC loads or electric grid [3]. Nowadays multilevel converters are widely used and recommended for medium and high voltage applications due to reduce switching losses, low harmonic distortion, high voltage capability and good dynamic response [4]. In general there are six main common multilevel converter topologies; Neutral point Clamped converter (NPC) [5], cascaded H-bridge [6], Y-connected Hybrid Cascaded [7], Capacitor Clamped [8], Z-source [9] and quasi Z-source [10]. The main circuit and control circuit of NPC three-level converter are simple compared with the traditional two-level topology. The main advantages of the NPC three-level inverter as follows: 1) reducing the harmonic and the switching frequency, so that the system loss is small, 2) rising rate of voltage(dv/dt) is lower than the two-level inverter and the rise rate of current (di/dt) is also reduced, 3) reducing the torque ripple and electromagnetic noise with the increase of the number of levels, each amplitude of level will be reduced relatively, 4) reducing the volume of the circuit because the voltage which is related to the absorption circuit is only half of that, the energy flowing into the absorption circuit is small. 
The main technical difficulty in any application of the NPC three-level topology is to maintain the two DC-side capacitors' voltages equal and at a pre-specified level, which is very important for the equipment running safely and reliably. Several methods have been used to retain the capacitor voltages at a desired value; the hardware implementation method including separate DC sources, an auxiliary converter to inject a current in the neutral point is used with additional circuit which adds to the equipment the inefficiency, cost and complexity and the software method is realized by modifying the converter-switching mode according to related control algorithms based on the space vector pulse width modulation (SVPWM) or sine pulse width modulation (SPWM) strategy.

For the SVPWM strategy, the related literatures adjust the action time of redundant small vectors by judging the direction of neutral-point current and the deviation of neutral-point potential with the increase of level numbers, this method is very complex and very difficult to realize because of the large amount of calculation. For the SPWM strategy, the algorithm is very simple by using zero-sequence component injection, and wouldn't increase as well as the increase of level numbers. However, the existing literatures can't accurately analysis the reason for the neutral-point potential drift and the effect of zero-sequence component by physical mechanism based on the accurate mathematical model. At the same time, these neutral-point potential balancing control strategies don't take the parametric perturbation into consideration. Accurate model of the NPC three-level converter with parametric perturbation is described in [11]. The output power of PV array is depend on irradiation which incident on the PV array surface over the time due to climatic conditions; the output power also varies producing several power-voltage curves for several irradiation levels. The maximum power output of PV array is generated by adjusting voltage or current for irradiation and temperature [12].

Maximum power point tracking control is used to improve the efficiency of photovoltaic power generation system. Several methods are using to get maximum power point of PV. Perturb-and-observe (P\&O) method is dominantly used in practical PV system for MPPT control due to its simple implementation. Look-up table would require large memory storage of the microcontroller as large amount of panel data is stored with high accuracy are implemented. Implement look-up table in a low cost microcontroller has limited memory space is usually difficult. In order to use curve-fitting efficiently on a low-cost microcontroller, $\mathrm{PV}$ emulator using multiple simple linear equations to mimic an $\mathrm{I}-\mathrm{V}$ curve of the PV panel to reduce computational time while maintaining sufficient accuracy and can be implemented in a low-cost 8-bit microcontroller is described in [13].

The converter current is included high order harmonic that flows into the grid causing harmonic pollution. Filters are used to eliminate these harmonics. The most common filter is L-filter while its inductance must be high value to decrease the current ripple. The LC-filter is used to eliminate these harmonics but it is expensive for medium and high power application as well as the filtering effect is not good because uncertainty of grid impedance. LCL filter had an inherently high cut-off frequency and strong penetrating ability in low frequency. So LCL filter has come into wide use in the inverter. The three-phase PV grid-connected inverters topology, firstly analyze the inductance, the ratio of two inductances, selecting the filter capacitor and resonance resistance. Based on these theories, a designed LCL filter is described in [14]. Also, low pass LCL filter is used to reduce PWM harmonic. A new state space approach for a low pass LCL filter connected between the converter station and the utility grid is described in terms of active and reactive power of the connecting buses, and dc voltage of the VSC described in [15]. The design of LCL filter is having one of the important roles in the entire system and plays vital role for stability of the system. The grid impedance is also having impact on the stability of the system and special care required in the design of LCL filter. The resonance frequency of LCL filter varies as the grid impedance varies i.e. stiffness of the grid. The LCL filter interfaced grid connected system is proposed and simulated with the design consideration for filter described in [16]. The electromagnetic interference filter (EMI) attenuates the high frequency current harmonics due to switching of inverter. For normal cases, the filter for grid coupled PV system includes only an inductance or an LC filter. The value of inductance for above-mentioned cases is very high, bulky and costly. The LCL filter worked as an EMI filter having common mode inductance and differential mode inductance.

In this paper, the digital control strategy of SPWM MPPT of PV system is designing for two cases; stand-alone and grid connected. Cheap and fast digital microcontroller named Microcontroller Arduino Nano 3x (which has clock speed $16 \mathrm{MHz}, 6 \mathrm{PWM}$ output terminals and $19 \mathrm{~mW}$ power consumption) is using two detect the irradiation value and control the SPWM by controlling the amplitude value of sine wave signal. The maximum power output with voltage curve of PV system is obtaining by changing inverter voltage in different irradiation values. This curve is using for look-up table of microcontroller with curve fitting. The NPC inverter is using for PV system where NPC inverter has high efficiency and the lowest THD. A designing of LCL-filter is investigating in this paper to reduce voltage and current harmonics within IEEE 
limit of medium and low voltage (5\%) which described in IEEE std 519-2014 and IEC 6100-4-12 [17]. MATLAB/SIMULINK is used for modelling PV system with external digital microcontroller.

\section{SYSTEM MODELLING}

Figure 1 shows the block diagram of PV system,

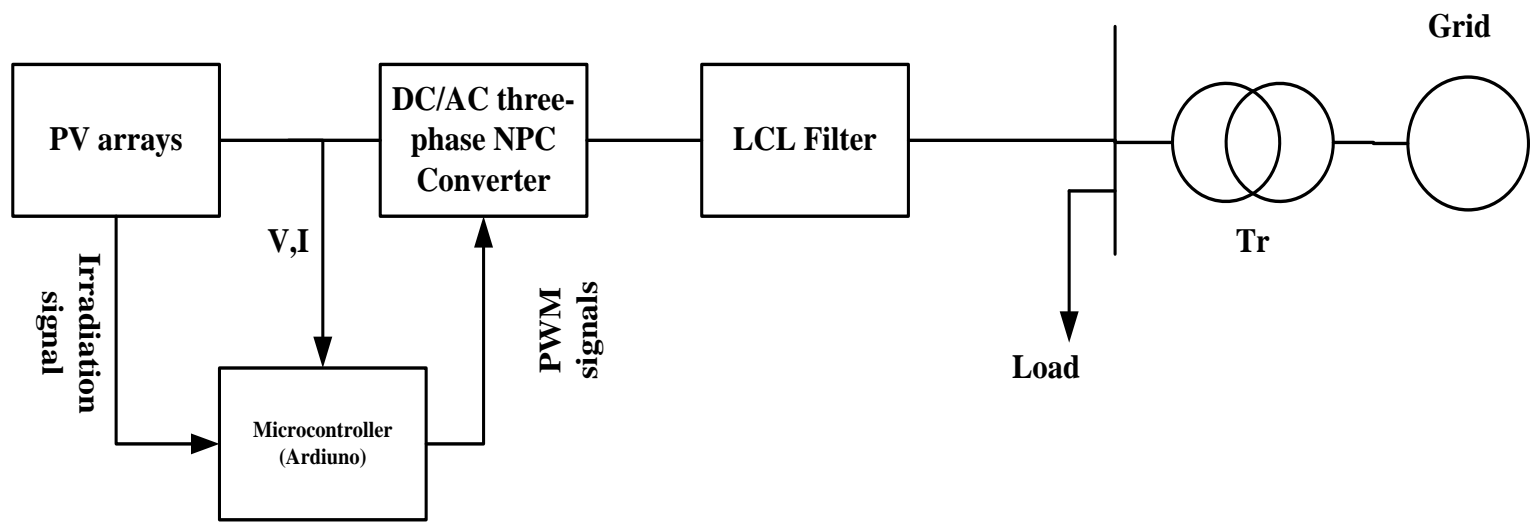

Figure 1. Block diagram of PV system

\section{SYSTEM DESCRIPTION}

Figure 2 shows grid-connected PV system. As shown in Figure 2, PV array is 800 modules, each module peak power is rated $250 \mathrm{~W}$ at $35 \mathrm{~V}$ and $5 \mathrm{~A}$, the number of Series-connected modules per string is 20 and the number of parallel strings is 40. PV array connected to three-phase three-level NPC converter controlled using SPWM of MPPT control. Three-phase LCL filter is used to connect the inverter output voltage to Three-phase load (stand-alone mode) or the grid (grid-connected mode). Digital microcontroller (Arduino Nano) controls the output voltage of inverter at maximum power point by generating SPWM signals. Digital microcontroller measures the signals of PV voltage and current to calculate maximum power point by $\mathrm{P} \& \mathrm{O}$ method.

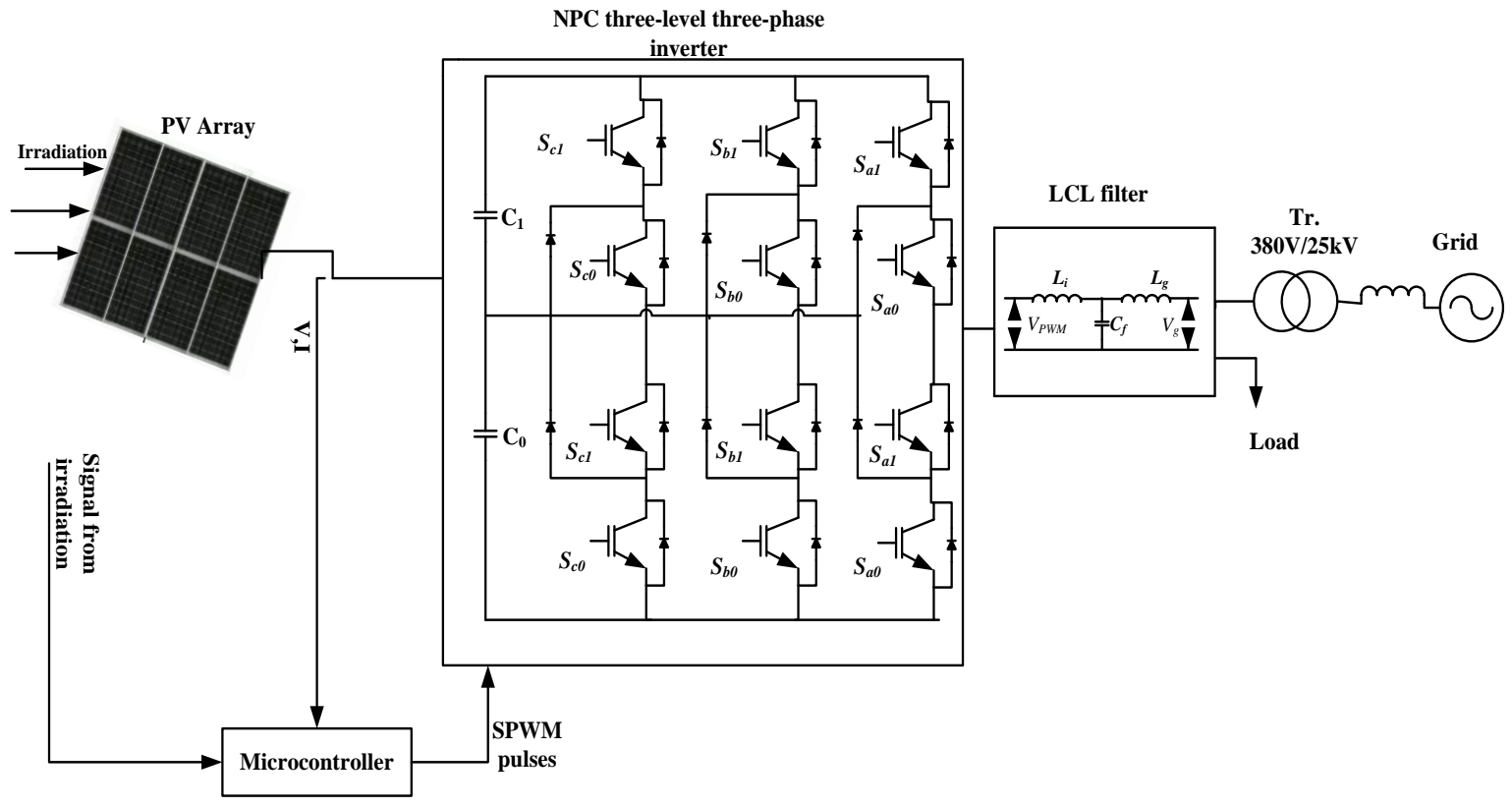

Figure 2. Grid-connected PV system 


\subsection{Photovoltaic cell $(\mathbf{P V})$}

Photovoltaic Cell is mainly a p-n junction with P-type silicon at the bottom and diffused thin layer of n-type on the top. PV cells produce current when photons incident on its surface [18]. Reference of different designs and models solar photovoltaic array of system suggests that the open circuit voltage of single solar cell is in between 0.5 and $0.7 \mathrm{~V}$ depending upon the material of solar cell. PV array module consists of number of series and parallel connected cells as per the required rating of PV array [16]. The equivalent circuit of a PV cell has a current source $\left(I_{p v}\right)$, a diode connected in anti parallel (D), a series resistor $\left(R_{s}\right)$ and a parallel resistor $\left(R_{p}\right)$ as shown in Figure 3 [19]. The equivalent resistances of PV array are:

$$
R_{s e}=R_{s}\left(\frac{N_{s}}{N_{p}}\right) R_{p e}=R_{p}\left(\frac{N_{S}}{N_{p}}\right)
$$

where $N_{s}=$ No. of series-connected modules per string, $N_{p}=$ No. of parallel strings

The output current of the PV cell is expressed as,

$$
I=I_{p v}-I_{s}\left\{\exp \left(\frac{q}{A_{k} T_{c} N_{s}} V+I R_{s}\right)-1\right\}-\frac{V+I R_{s}}{R_{p}}
$$

where $I_{p v}$ denotes light generated current, $I_{s}$ is the saturation current of the diode, $\mathrm{q}$ is the electron charge which is $1.60 \times 10^{-19}$ C. $V$ and $I$ denote the output voltage and the output current of the PV cell respectively. The ideality factor of the cell is defined as $A_{k}$ in the equation is Boltzmann constant $\left(1.38 \mathrm{x} 10^{-23} \mathrm{~J} / \mathrm{K}\right)$. The number of series connected cells in a PV module is denoted by $N_{s}$. The light generated current $\left(I_{p v}\right)$ in (2) is expressed as,

$$
I_{p v}=\left[I_{s c}+K_{f}\left(T_{c}-T_{r e f}\right)\right] \cdot G
$$

where $K_{f}$ is the temperature co-efficient of short circuit current of the cell. $T_{c}$ and $T_{r e f}$ are the cell's operating temperature and reference temperature respectively. $G$ is the solar irradiation level in $\mathrm{W} / \mathrm{m}^{2}$,

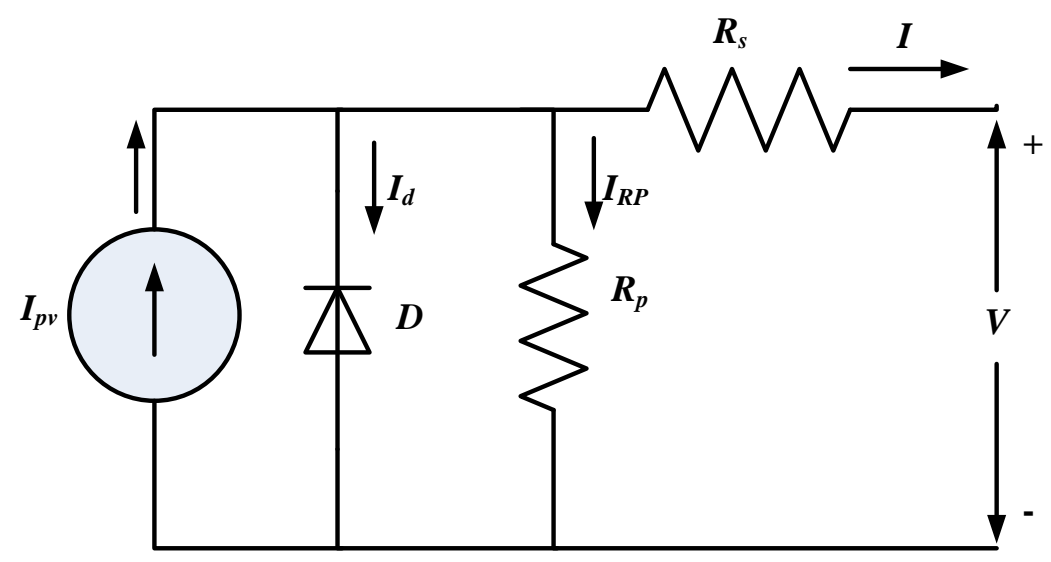

Figure 3. Equivalent circuit of PV cell

\subsection{Maximum power point tracking (MPPT)}

In this model, Perturb-and-Observe (P\&O) method is used. This method works by calculating the current output power for step $(P(k))$ for the current values of voltage $\left(V_{p h}(k)\right)$ and current $\left(I_{p h}(k)\right)$, then compare it with the previous output power values $(P(k-1))$. In case of power increases, change the voltage in the same direction as the previous change. Otherwise, change the voltage in the opposite direction of the previous one [18]. Figure 4 shows the flow chart of the P\&O method. 


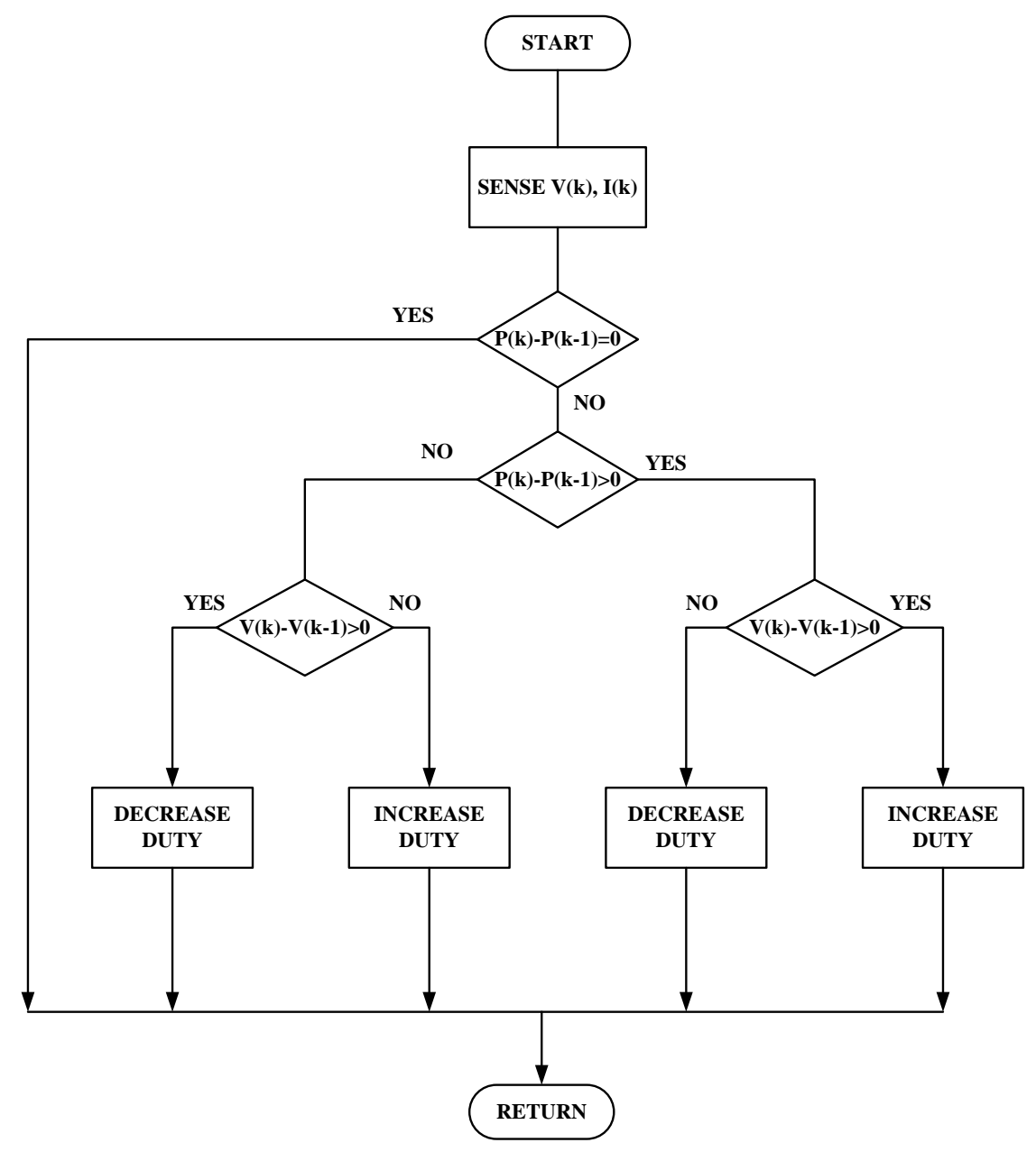

Figure 4. The flow chart of the $\mathrm{P} \& \mathrm{O}$ method

\subsection{Three-level neutral point clamped converter (NPC)}

The number of levels of a converter is the number of steps in the voltage of the output terminals with respect to any arbitrary internal reference point. Three level NPC as shown in Figure 2, characterized by obtaining the lowest THD (36.22\%) and very high efficiency (98.93\%) in comparing with other multilevel converters topologies mentioned before [20]. It is necessary to model three-phase inverters to obtain voltage and current waveforms for each element like IGBT and diode, working out the power losses accurately. There are three legs which are denoted by a, b, c.

Each leg has four switches and two diodes. For ideal switch, $V_{a}$ is the output voltage for phase a, $V_{L}$ and $I_{L}$ are the inductor voltage and current, $\mathrm{L}$ is the AC-side filter inductance, $r_{L}$ is the winding resistance related to the inductance $\mathrm{L}, R_{\text {Load }}$ is the load resistance and $V_{N}$ is the neutral point voltage. Starting from $V_{j}=\mathrm{a}, \mathrm{b}, \mathrm{c}, \mathrm{a} \mathrm{KVL}$ can relate $V_{j}$ to $V_{N}$ as below [21].

$$
V_{j}=L \frac{d I_{L j}}{d t}+I_{L j} r_{L}+I_{L j} R_{\text {Load }}+V_{N},(j=a, b, c)
$$

Also, the neutral point voltage can be related to the phase voltages in three-phase systems,

$$
V_{N}=\left(V_{a}+V_{b}+V_{c}\right) / 3
$$

Combining (4) with (5) as well as doing further rearrangement for getting two independent inductor currents leads to,

$$
\frac{d I_{L a}}{d t}=-\frac{I_{L a}\left(r_{L}+R_{L o a d}\right)}{L}+\frac{1}{3 L}\left(2 V_{a}-V_{b}-V_{c}\right)
$$




$$
\frac{d I_{L b}}{d t}=-\frac{I_{L b}\left(r_{L}+R_{L o a d}\right)}{L}+\frac{1}{3 L}\left(2 V_{b}-V_{a}-V_{c}\right)
$$

In order to avoid the inner switches suffering from high voltage, the outer two switches are not allowed to be in on state at the same time. So there are three different voltage outputs, and this is the reason why it is called three-level [22].

\subsection{Design of LCL filter}

The LCL filter as shown in Figure 2, designing is categorized into two parts. First part deals with the design of inverter-side inductance $\left(L_{i}\right)$ and the second part deals with the design of grid-side inductance $\left(L_{g}\right)$ and capacitance $\left(C_{f}\right)$ which is considered as $L_{g} C_{f}$ second order low pass filter. The grid-side inductance design is having relation with inverter-side inductance and the ratio between grid-side inductance and converter side inductance depends upon the ripple current attenuation. The simplified equations are used for the designing of LCL filter [16].

$$
\begin{aligned}
& L_{i}=\frac{V_{s}}{2 \sqrt{6} f_{s} i_{\text {ripple }}} \\
& C_{f}=\frac{0.05}{\omega_{n} Z_{\text {base }}} \\
& Z_{\text {base }}=\frac{V_{\text {sll }}^{2}}{P_{n}} \\
& L_{g}=L_{i}
\end{aligned}
$$

where $V_{s}$ is grid r.m.s. phase voltage, $f_{s}$ is inverter switching frequency, $i_{\text {ripple }}$ is expressed as a percentage of the inverter current $I_{i n v}$ which lies in the range $5 \%-25 \%, L_{g}$ is grid-side inductance, $L_{i}$ is inverter-side inductance, $C_{f}$ is capacitance of LCL filter, $P_{n}$ is inverter rated power and $\omega_{n}$ is operating frequency.

Splitting the total filter inductance $L_{T}$ into $L_{i}$ (inverter-side inductance) and $L_{g}$ (grid-side inductance) follows the relationship:

$$
L_{g}=r * L_{g}
$$

where $r(0.4<r<2)$ is the inductance index [23-25]. However, the following limitations on the filter parameters have been taken into account [23]:- The total inductance $\left(L_{T}=L_{i}+L_{g}\right)$ should be less than 0.1 (p.u) because it results in ac voltage drop during operation. Otherwise, a higher dc-link voltage will be required and this results in higher switching losses. However, for high power levels, the main aim is to avoid the saturation of the inductors $L_{i}$ and $L_{g}$. The capacitance is limited by the reactive power limit (normally this limit is less than $5 \%$ ).- To avoid resonance problems, the resonance frequency $\omega_{\text {res }}$ of the filter should be higher than 10 times the grid frequency $\omega$ and smaller than half of the switching frequency $\omega_{s w}$.

\subsection{Sinusoidal pulse width modulation}

The generation of a sinusoidal PWM signal finds more applications in industries, which can be generated by comparing a sinusoidal reference signal with a sawtooth carrier wave and the width of each pulse varied proportionally to the amplitude of a sine wave evaluated at the center of the same pulse. The output frequency of the inverter can be found by using the frequency of the reference signal. The rms output voltage can be controlled by modulation index and in turn modulation index is controlled by peak amplitude. The gating signal can be produced by using the variable frequencies unidirectional sawtooth carrier wave [26]. Figure 5 shows one signal SPWM generation of specific frequency of sawtooth. The frequency of PWM represents the amount of time taken by PWM to complete one cycle. In order to produce variable values, the sawtooth frequency can be changed In order to make the analysis of control PWM it is necessary to define some parameters. The index of amplitude modulation $m_{a}$ and index of frequency modulation,

$$
m_{f}: m_{a}=\frac{V_{\text {ref }}}{V_{\text {saw }}}, m_{f}=\frac{f_{\text {saw }}}{f_{\text {ref }}}
$$



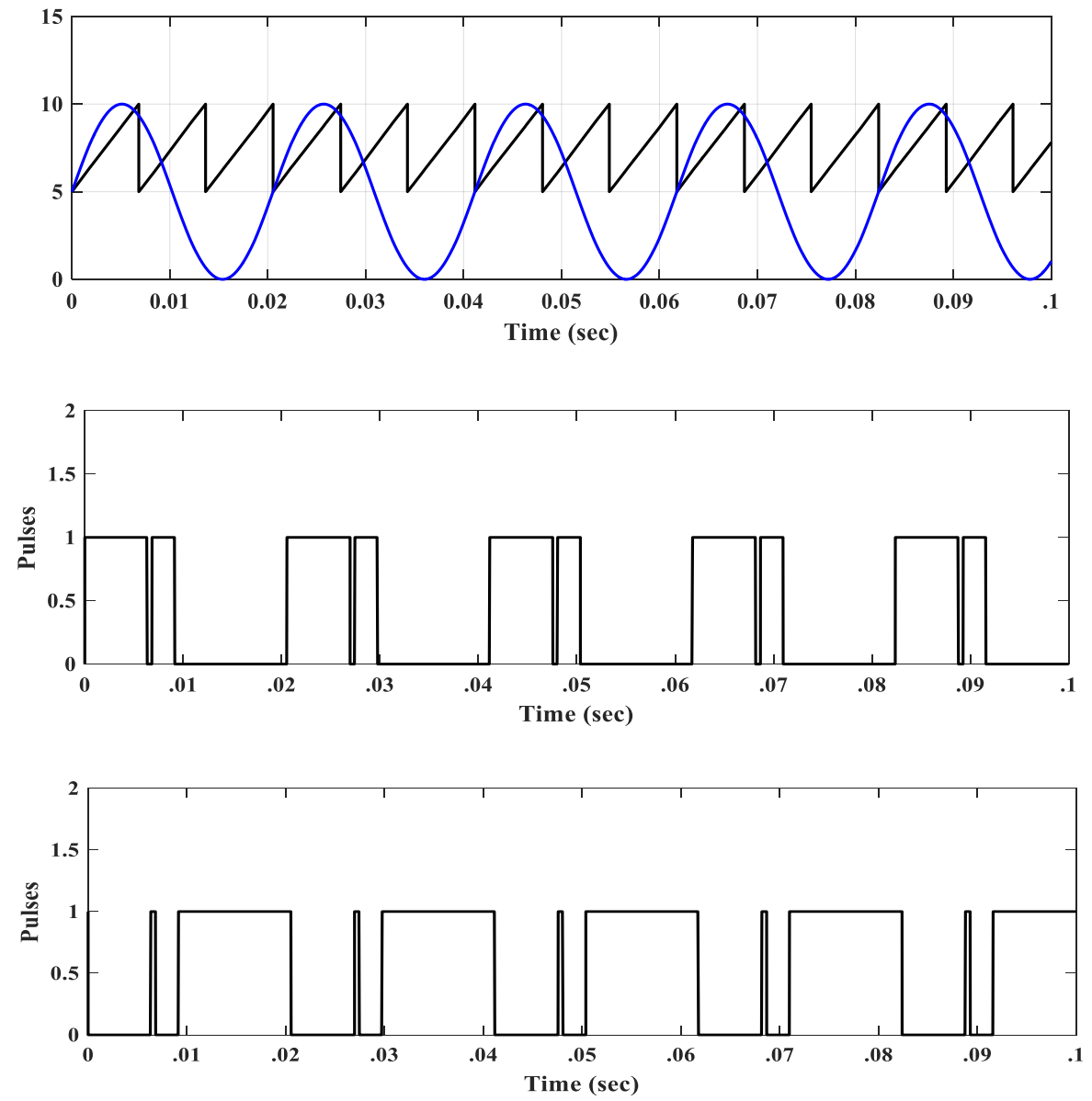

Figure 5. one signal SPWM generation of specific frequency of sawtooth

\subsection{Microcontroller}

The Arduino Nano 3.x is a small, complete, and breadboard-friendly board based on the ATmega328. It has more or less the same functionality of the Arduino Duemilanove, but in a different package. It lacks only a DC power jack, and works with a Mini-B USB cable instead of a standard one. Ardino specifications are $5 \mathrm{~V}$ operating voltage, $19 \mathrm{~mW}$ power consumption and $16 \mathrm{MHz}$ clock speed. The Arduino clock frequency is $16 \mathrm{MHz}$ that a pulse-width-modulated (PWM) signal, using the hardware timers on the ATmega328 might be the way to go. This gives very precise and consistent timing and allows to toggle a pin as fast as $f_{P C U}$. The delay time response of Arduino and its effect on simulation-based model are negligible.

\section{CONTROL STRATEGY}

MPPT curve of PV array is obtaining using P\&O method. In this method, the RMS value of output voltage of inverter is changing using SPWM. SPWM is controlled by amplitude of sine wave signal which compares with sawtooth signal. To get MPP of PV array in the variable irradiation using following steps:

a) Irradiation is changing from $100 \mathrm{~W} / \mathrm{m}^{2}$ to $1000 \mathrm{~W} / \mathrm{m}^{2}$ by step 100 .

b) Microcontroller is changing the amplitude of sine wave signal of SPWM to get MPP in specific irradiation.

c) Recording MPP with the amplitude of sine wave signal of SPWM.

From the above steps, we are obtained MPPT curve with the amplitude of sine wave signal of SPWM. This curve is used as look-up table employed in Microcontroller with curve fitting.

Digital control strategy is using to PV system by Microcontroller as the following:

a) Measure the value of irradiation then feed to Microcontroller.

b) Using Look-up table of MPPT, Microcontroller is adjusting the amplitude of sine wave signal of SPWM. 


\section{SIMULATION RESULTS}

Stand-alone and grid-connected PV system is simulated using MATLAB/SIMUINK with coupling Microcontroller Arduino Nano by USB cable. Figure 6 shows MATLAB/SIMUINK of PV system connected Arduino Nano using USB.

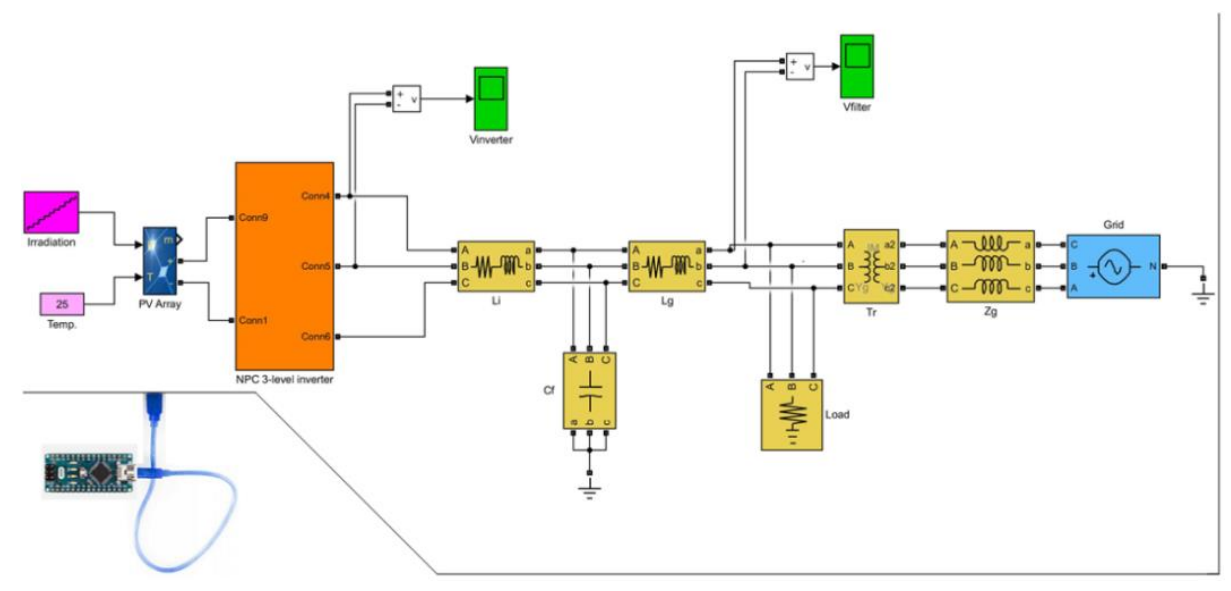

Figure 6. MATLAB/SIMUINK of PV system connected Arduino Nano using USB

\subsection{LCL filter design}

The design of inverter-side inductance $\left(L_{i}\right)$ and the second part deals with the design of grid-side inductance $\left(L_{g}\right)$ and capacitance $\left(C_{f}\right)$ of LCL filter using the rated values of the PV system; $V_{s}=220 \mathrm{~V}$, $V_{\text {sll }}=380 \mathrm{~V}, f_{s}=50 \mathrm{~Hz}, P_{n}=800 * 250 \mathrm{~W}=200 \mathrm{~kW}, \mathrm{I}_{n}=5 \mathrm{~A} * 40=200 \mathrm{~A}, \quad i_{\text {ripple }}=0.15 * \mathrm{I}_{n}=$ $30 \mathrm{~A}$ are: $L_{i}=0.0299 \mathrm{H} \approx 30 \mathrm{mH}=L_{g}$ and $C_{f}=220 \mu \mathrm{F}$

\subsection{Maximum power curve}

Matlab/Simulink is using to simulate controlled three-level three-phase NPC converter gate switching using variable modulation indices with carrier signal sampling frequency $100 \mathrm{KHz}$ and reference signal frequency $50 \mathrm{~Hz}$, with irradiation of $1000 \mathrm{w} / \mathrm{m}^{2}$ and temperature of 25 degree c. To obtain the maximum power-voltage curve of PV array, the peak value of sinusoidal wave of controlling SPWM is changing to get the inverter voltage value of maximum power in different irradiation $\left(100 \mathrm{~W} / \mathrm{m}^{2}\right.$ to 1000 $\mathrm{W} / \mathrm{m}^{2}$ ). Figure 7 shows the $\mathrm{P}-\mathrm{V}$ maximum power curve. The proportional relation between rms output voltages of filter is increasing with the output power of the solar panel while increasing the modulation index of the SPWM controlled by MPPT. This curve with curve fitting in different points is using as look-up table employed in microcontroller.

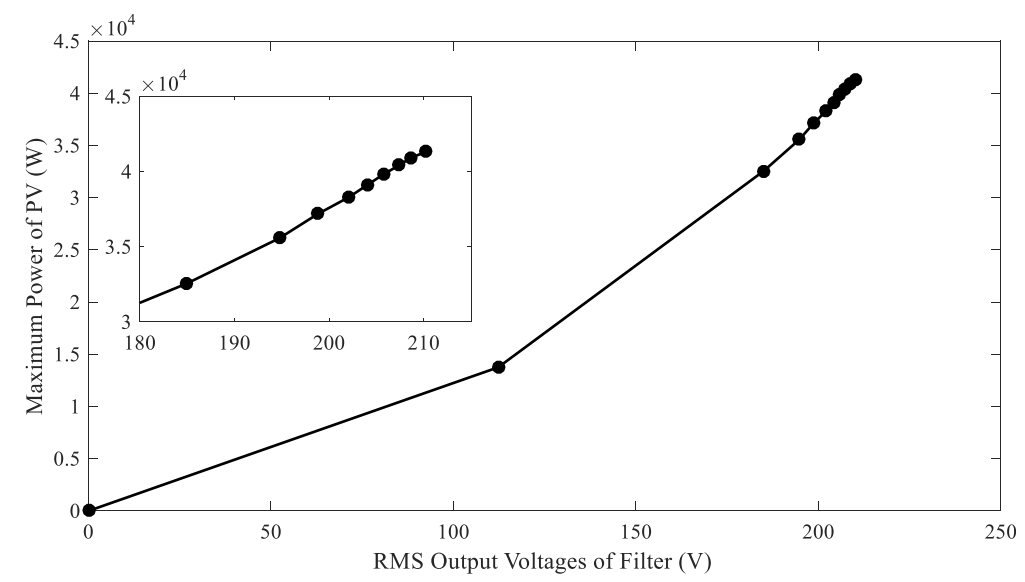

Figure 7. P-V maximum power curve 


\subsection{Case 1: Stand-alone PV system}

The PV system connected to three-phase load, in Figure 2, was simulated in irradiation of 1000 $\mathrm{W} / \mathrm{m}^{2}$ and temperature of 25 degree using Matlab/Simulink. Figure 8 shows the output voltages of the inverter before and after the filter and their harmonics. As shown in Figure 8, the THD is very small approximately $22 \%$ using to control SPWM of three-level three-phase converter. The LCL filter is used to reduce THD to $4.9 \%$ within IEEE limit of medium and low voltage (5\%). Stand-alone PV system with threephase load, in Figure 2, was simulated in variable irradiation from 100 to $1000 \mathrm{~W} / \mathrm{m}^{2}$ and temperature of 25 degree using Matlab/Simulink. Figure 9 shows DC output voltage and power of PV array. Figure 10 shows output power of inverter and load.

As shown in Figure 9, DC voltage of PV array is changing from $420 \mathrm{~V}$ at $100 \mathrm{~W} / \mathrm{m}^{2}$ to $620 \mathrm{~V}$ at 200 $\mathrm{W} / \mathrm{m}^{2}$. DC voltage of PV array is changing with small from $620 \mathrm{~V}$ to $782 \mathrm{~V}$ with irradiation change from 200 to $1000 \mathrm{~W} / \mathrm{m}^{2}$. As well as DC power of PV array is changing from $15 \mathrm{~kW}$ at $100 \mathrm{~W} / \mathrm{m}^{2}$ to $36 \mathrm{~kW}$ at 200 $\mathrm{W} / \mathrm{m}^{2}$. DC power of PV array is changing with small from $36 \mathrm{~kW}$ to $39 \mathrm{~kW}$ with irradiation change from 200 to $1000 \mathrm{~W} / \mathrm{m}^{2}$. As shown in Figure 10 , the load power is variable from $2500 \mathrm{~W}$ at $100 \mathrm{~W} / \mathrm{m}^{2}$ to $6000 \mathrm{~W} 1000$ $\mathrm{W} / \mathrm{m}^{2}$ where it depends on voltage and irradiation. The power loss of LCL filter is approximately zero which is the difference between the output power of inverter and output power of filter.

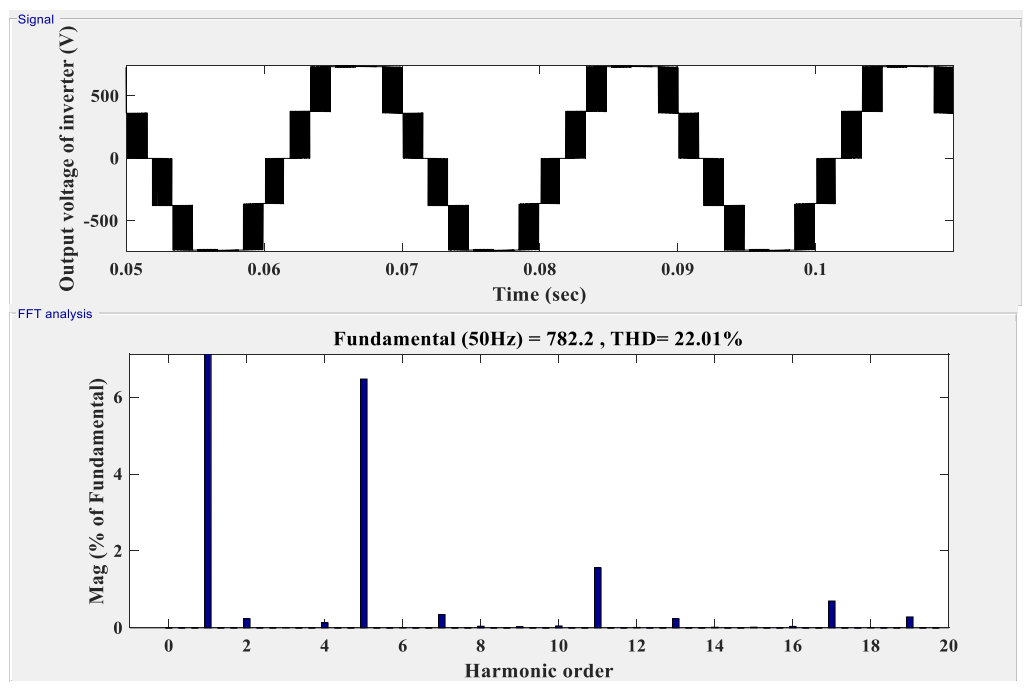

Figure 8(a). The output voltage of the inverter and harmonics

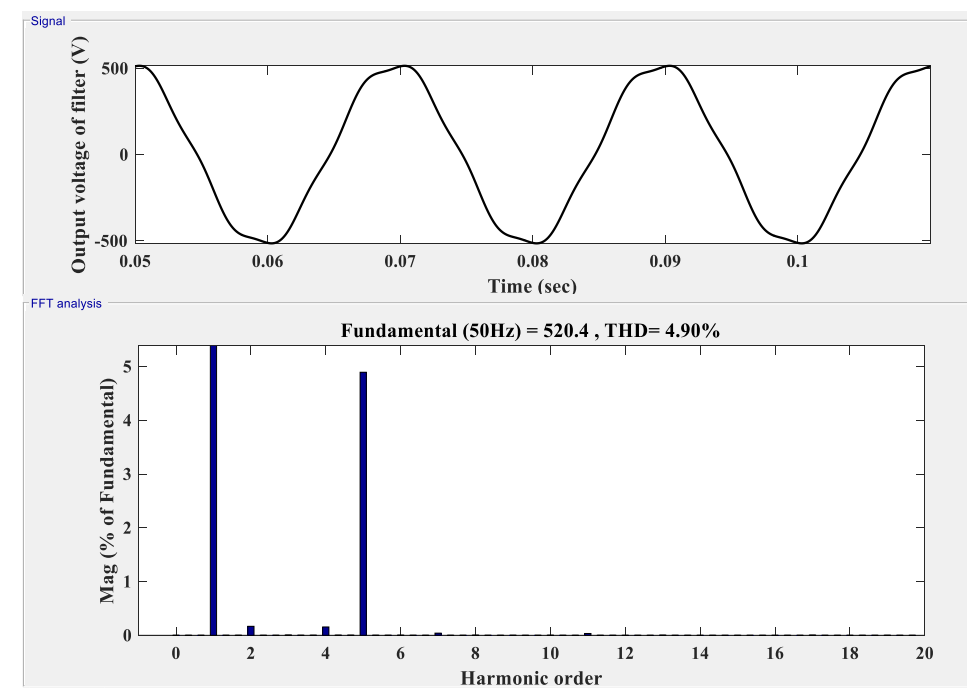

Figure $8(\mathrm{~b})$. The output voltage filter and harmonics 

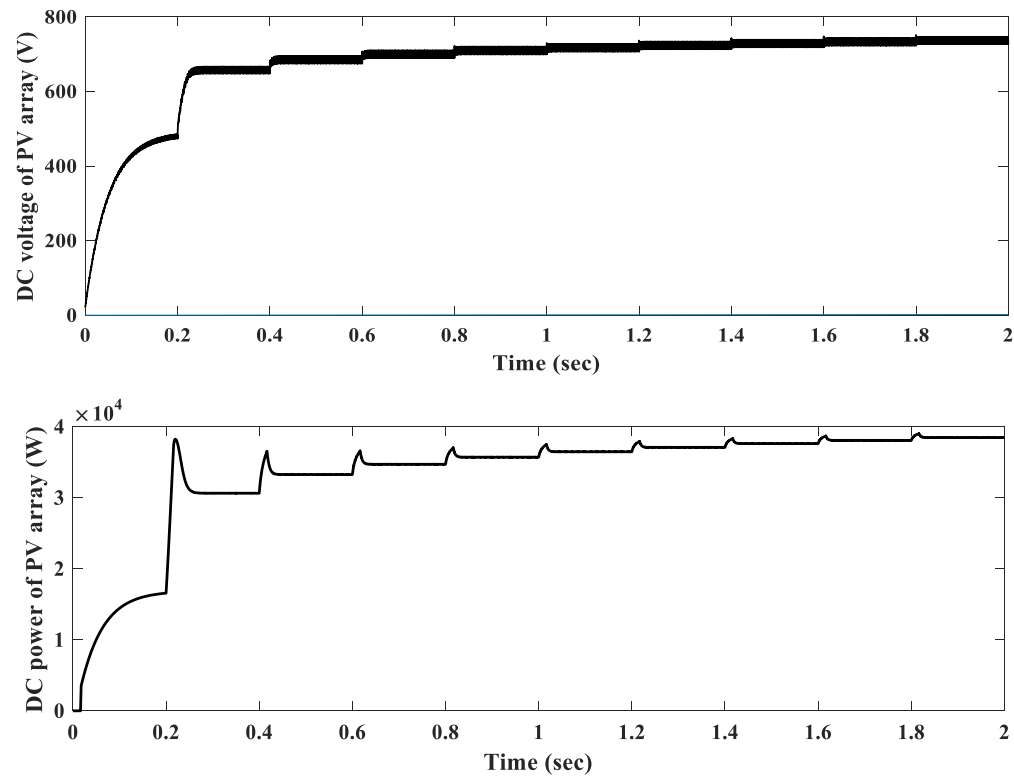

Figure 9. DC output voltage and power of PV array
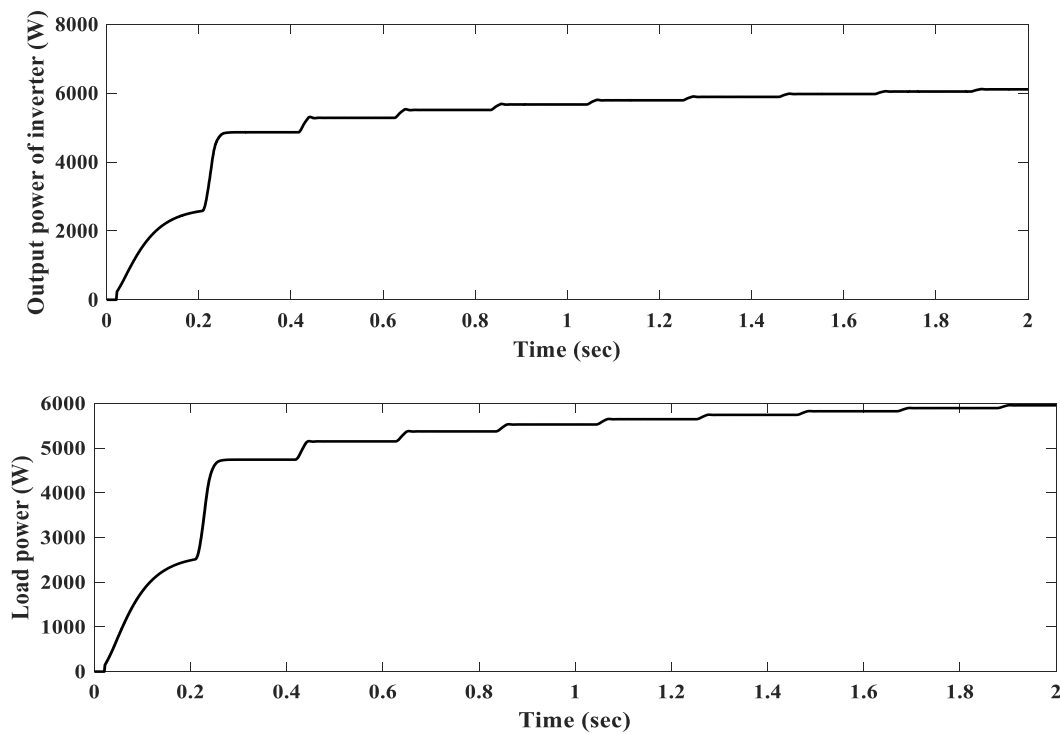

Figure 10. Output power of inverter and load

\subsection{Case 2: Grid-connected PV system}

The Grid-connected PV system with three-phase load, in Figure 2, was simulated in irradiation of $1000 \mathrm{~W} / \mathrm{m}^{2}$ and temperature of 25 degree using Matlab/Simulink. Figure 11 shows the output voltages of the inverter before and after the filter and their harmonics. As shown in Figure 11, the THD is very small approximately $22 \%$ using to control SPWM of three-level three-phase converter. The LCL filter is used to reduce THD to $3.51 \%$ within IEEE limit of medium and low voltage (5\%).

The Grid-connected PV system with three-phase load, in Figure 2, was simulated in variable irradiation from 100 to $1000 \mathrm{~W} / \mathrm{m}^{2}$ and temperature of 25 degree using Matlab/Simulink. Figure 12 shows DC output voltage and power of PV array. Figure 13 shows output power of inverter, filter, load and grid. As shown in Figure 12, DC voltage of PV array is changing from $300 \mathrm{~V}$ at $100 \mathrm{~W} / \mathrm{m}^{2}$ to $620 \mathrm{~V}$ at $200 \mathrm{~W} / \mathrm{m}^{2}$. DC voltage of PV array is changing with small from $620 \mathrm{~V}$ to $782 \mathrm{~V}$ with irradiation change from 200 to $1000 \mathrm{~W} / \mathrm{m}^{2}$. As well as DC power of PV array is changing from $10 \mathrm{~kW}$ at $100 \mathrm{~W} / \mathrm{m}^{2}$ to $36 \mathrm{~kW}$ at $200 \mathrm{~W} / \mathrm{m}^{2}$. DC power of PV array is changing with small from $36 \mathrm{~kW}$ to $42 \mathrm{~kW}$ with irradiation change from 200 to 
$1000 \mathrm{~W} / \mathrm{m}^{2}$. As shown in Figure 13, the load power is constant value $(=22 \mathrm{~kW})$. The PV system and grid is feeding load in different values of irradiation. The power loss of LCL filter is approximately zero which is the difference between the output power of inverter and output power of filter.

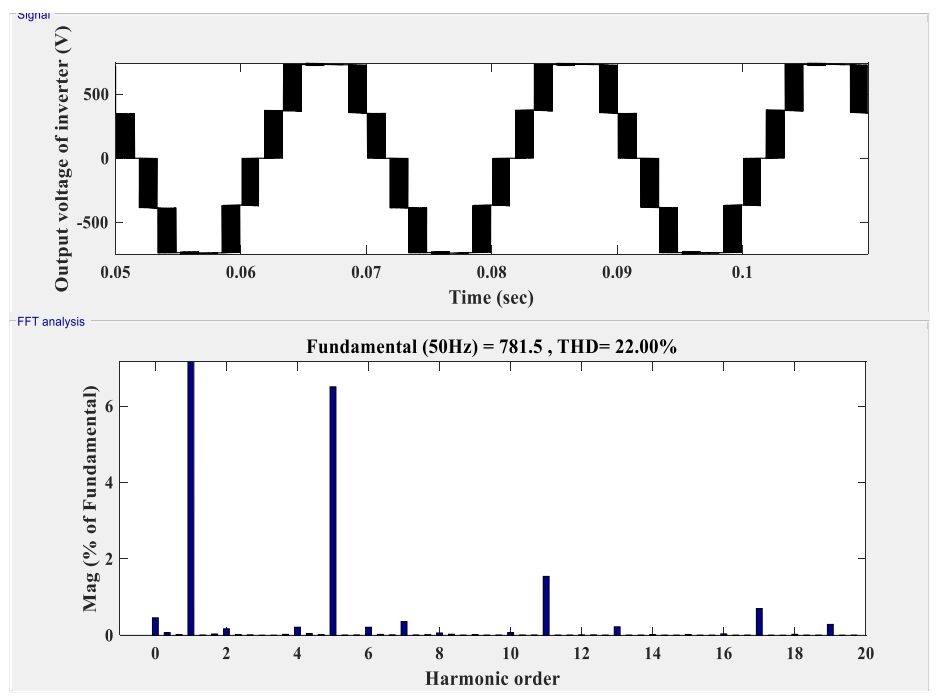

Figure 11(a) The output voltage of inverter and harmonics
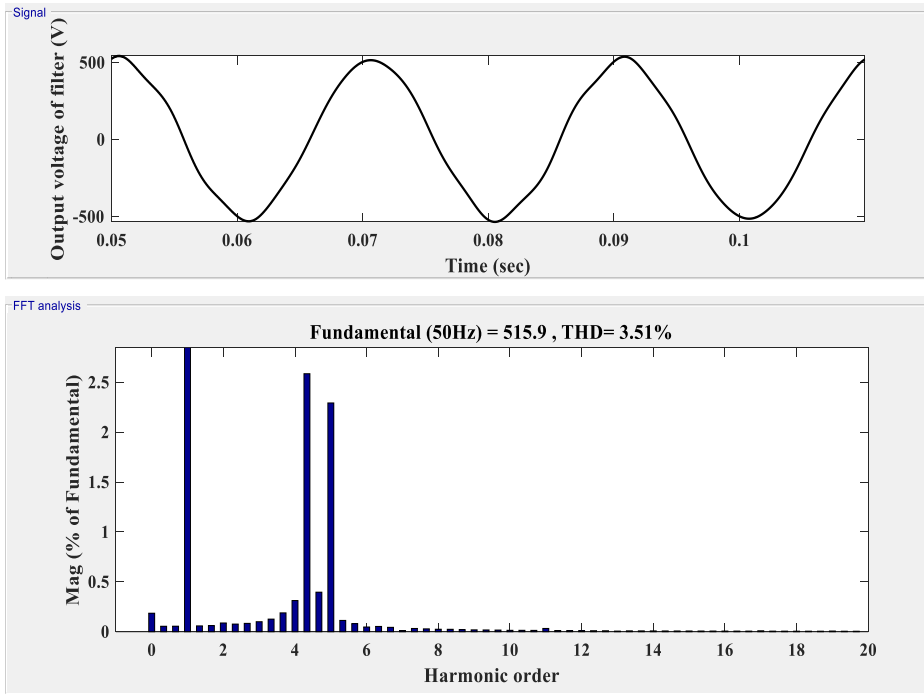

Figure 11(b). The output voltage of filter and harmonics

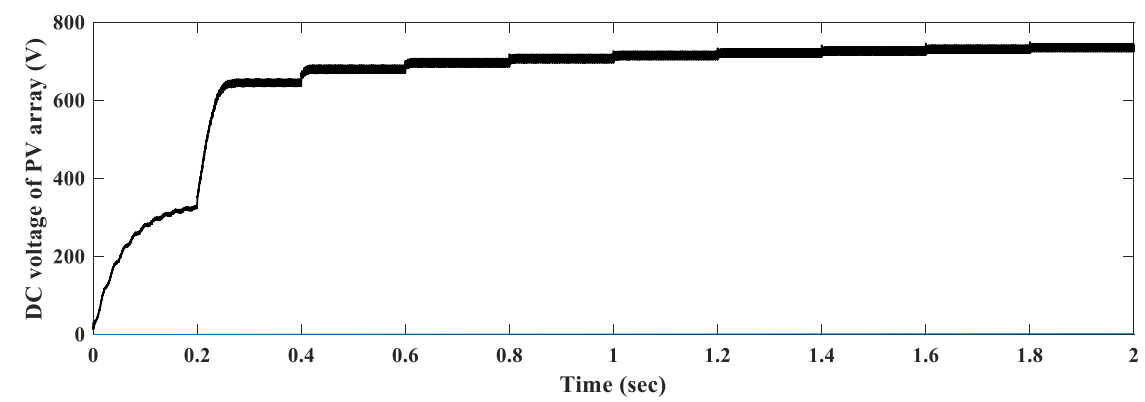




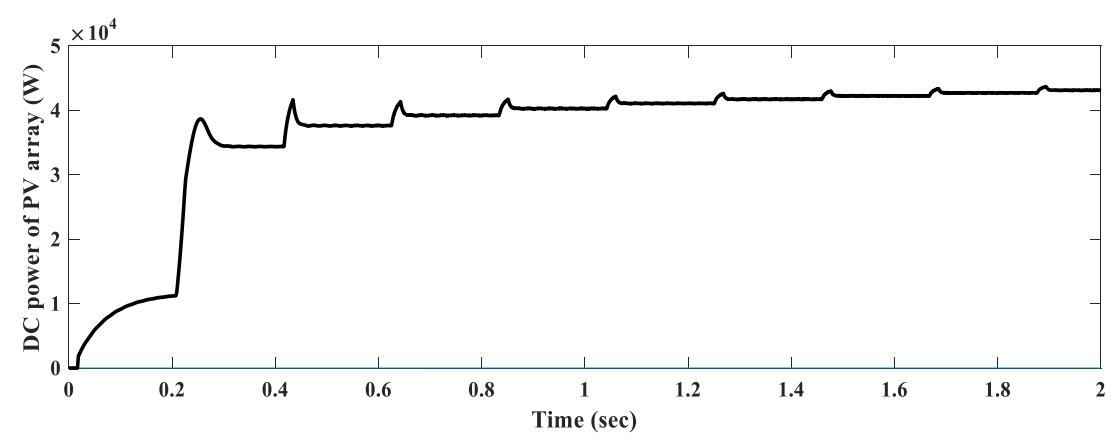

Figure 12. DC output voltage and power of PV array
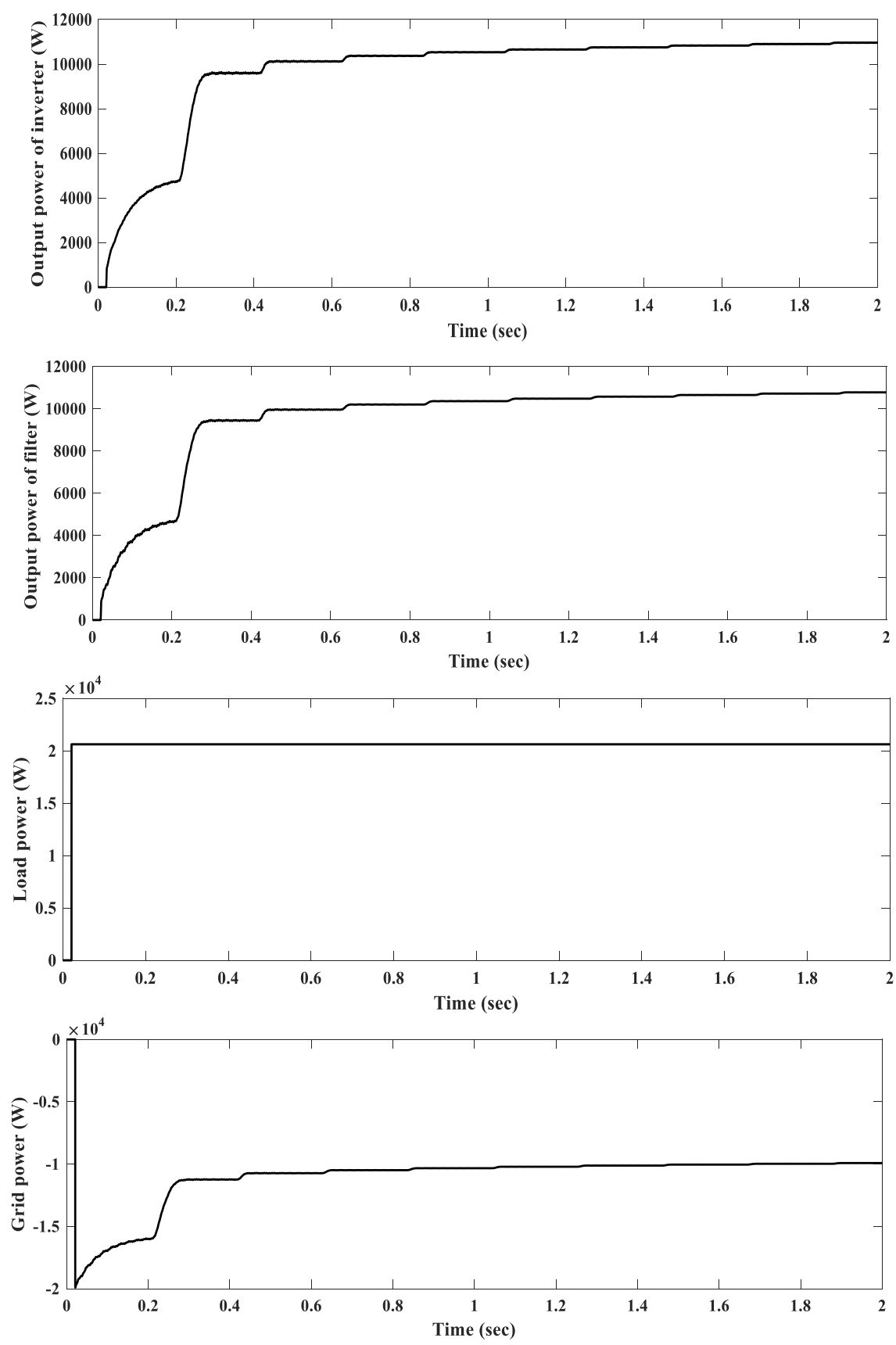

Figure 13. Output power of inverter, filter, load and grid 


\section{CONCLUSION}

Configuration of MPPT control with multilevel converter gate signals is one of the most effective ways to optimise PV systems with high performance. Avoiding low amplitude modulation indices to make the best use of three-level converter utilities. Look up table for the values of optimum voltage that achieve the maximum power for each irradiation value is used for digital control signal in microcontroller. The simple and fast method to get MPP of PV system with variable irradiation is digital control where the maximum power point is obtained from look-up table. The output voltage harmonic of multi-level threephase inverter is controlled using SPWM control. THD of output voltage of multi-level three-phase NPC inverter is $22 \%$ to stand-alone and grid-connected PV system. Small rate lossless LCL filter is used to limit voltage harmonics within medium and low voltage limits (5\%). THD output voltage of filter is $4.9 \%$ and $3.51 \%$ of stand-alone and grid-connected PV system respectively.

\section{REFERENCE}

[1] Muoka, Md. Enamul Haque, Ameen Gargoom, and Michael Negnevitsky, "DSP-Based Hands-On Laboratory Experiments for Photovoltaic Power Systems", IEEE Transactions On Education, vol. 58, no. 1, pp. 39-47, 2015.

[2] Zabihinejad and P. Viarouge, "Design of Direct Power Controller for a High Power Neutral Point Clamped Converter using Real time Simulator” World Academy of Science, Engineering and Technology, Energy and Power Engineering, vol. 1, no.1, pp. 187, 2014.

[3] Rodriguez, J., Bernet, S., Steimer and P.K., Lizama, I.E.,”A Survey on Neutral-Point-Clamped Inverters", IEEE Trans. on Ind. Elec., vol.57, no.7, pp. 2219-2230, 2010.

[4] Abbes M, Behadi J, Ben Abdelghani Bennai A., "Design and Control of a direct drive wind turbine equipped with multilevel converters". Renewable Energy, vol. 35, no. 5, pp. 936-945, 2014.

[5] Nabae, I. Takahashi and H. Akagi, "A new neutral point clamped PWM inverter", IEEE Trans. Ind. Appl., vol. 17, no.5, pp. 518-523, 1981.

[6] P. W. Hammond," A new approach to enhance power quality for medium voltage AC drives", IEEE Trans. Ind. Appl., vol. 33, no. 1, pp. 202-208, 1997.

[7] F. Khoucha, S. MounaLagoun, K. Marouani, A. Kheloui and M. Benbouzid,"Hybrid Cascaded H-Bridge Multilevel-Inverter Induction Motor-Drive Direct Torque Control for Automotive Applications". IEEE Transactions on Industrial Electronics, Institute of Electrical and Electronics Engineers, vol. 57, no. 3, pp. 892-899, 2010.

[8] T. A. Meynard, H. Foch, P. Thomas, J. Couralt, R. Jakob, and m. Naherstaedt, "Multicel converters: Basic concepts and industry application", IEEE Trans. Ind. Electron., vol. 49, no. 5, pp. 955-964, 2002.

[9] F. Z. Peng, "Z-source inverter", IEEE Trans Ind. Appl., vol. 39, no. 2, pp. 504-510, 2003.

[10] Y. Li, J. Anderson, F. Z. Peng, and D.Liu, "Quasi-Z-source inverter for photovoltaic power generation systems". 24th Ann. IEEE Appl. Power Elect. Conf, Washington, DC, pp. 918-924, 2009.

[11] M. Zhang, B. Chi, X. Wang, Q. Wang and G. Li," Study on Neutral-Point Potential Control for the NPC ThreeLevel Converter", 2016 IEEE 11th Conference on Industrial Electronics and Applications (ICIEA), pp. 1-5, 2016.

[12] C. Protogeropoulos, B. J. Brinkworth, R. H. Marshall and B. M. Cross, "Evaluation of Two Theoretical Models in Simulating the Performance Of Amorphous-Silicon Solar Cells," 10th European Photovoltaic Solar Energy Conference, Lisbon, Portugal, 1991.

[13] Dylan D.C. Lu and Quang Ngoc Nguyen,” A photovoltaic panel emulator using a buck-boost DC/DC converter and a low cost micro-controller", Solar Energy, vol. 86, no. 5, pp. 1477-1484, 2012.

[14] Xu Renzhong, Xia Lie, Zhang Junjun, and Ding Jie, " Design and Research on the LCL Filter in Three-Phase PV Grid-Connected Inverters", International Journal of Computer and Electrical Engineering, vol. 5, no. 3, pp. 322-325, 2013.

[15] S. Dhar and P.K. Dash," Adaptive back stepping sliding mode control of a grid interactive PV-VSC system with LCL filter", Sustainable Energy, Grids and Networks, vol. 6, pp. 109-124, 2016.

[16] R. N. Tripathi, A. Singh and T. Hanamoto," Design and control of LCL filter interfaced grid connected solar photovoltaic (SPV) system using power balance theory", Electrical Power and Energy Systems, vol. 69, pp. 264-272, 2015.

[17] IEEE Std 519-2014, "IEEE Recommended Practices and Requirements for Harmonic Control in Electrical Power Systems", New York, NY: IEEE, 2014.

[18] M. Abdel-Salam, A. Ahmed, M. Amery, M. Swify, A. El-kousy and Kh. Sayed, " Design and Implementation of Stand-alone Residential PV System ", 2011 IEEE Jordan Conf. on Applied Electrical Engineering and Computing Technologies (AEECT), pp. 1-5, 2011.

[19] S. Sheik Mohammed, D. Devaraj, T. P. Imthias Ahamed, " Maximum power point tracking system for standalone solar PV power system using Adaptive Neuro-Fuzzy Inference System”, 2016 Biennial International Conference on Power and Energy Systems: Towards Sustainable Energy (PESTSE), pp. 1-4, 2011.

[20] Delavari, I. Kamwa and A. Zabihinejad, "A Comparative Study of Different Multilevel Converter Topologies for High Power Photovoltaic Applications". 7thPower Electronics, Drive Systems \&Technologies Conference (PEDSTC 2016), Iran University of Science and Technology, Tehran, Iran, 2016. 
[21] Yousef Firouz, Mohammad Tavakoli Bina and Bahman Eskandari," Efficiency of three-level neutral-point clamped converters: analysis and experimental validation of power losses, thermal modelling and lifetime prediction", IET Power Electron., vol. 7, no. 1, pp. 209-219, 2014.

[22] Xinbo Cai, Zhenbin Zhang, Zhe Chen and Ralph Kennel," DC-bus Voltage Balancing for Three-level NPC Inverter Using Deadbeat Controller", 2016 IEEE 8th International Power Electronics and Motion Control Conference IPEMC-ECCE Asia, pp. 1-6, 2016.

[23] M. Liserre, F. Blaabjerg, and S. Hansen, "Design and control of an LCL filter based three-phase active rectifier". IEEE Transactions on Industry Applications, vol. 41, no. 5, pp. 1281-1291, 2005.

[24] B. Bolsens, K. Brabandere, J. Keybus, J. Driesen, R. Belmans, "Model-based generation of low distortion currents in grid-coupled PWM inverters using an LCL output filter", IEEE Tran. on P. Elec., vol. 21, no. 4, pp. 1032-1040, 2006.

[25] H. Cha and T-K. Vu, "Comparative analysis of low-pass output filter for single-phase grid-connected photovoltaic inverter", IEEE Applied Power Electronics Conference and Exposition (APEC), USA, pp. 1659-1665, 2010.

[26] Muhammad H. Rashid, 2001,"Power Electronics Handbook", Academic Press.

\section{BIOGRAPHIES OF AUTHORS}
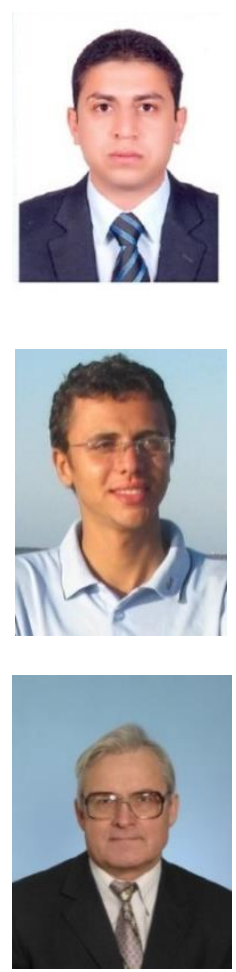

Mahmoud M.A. Aref was born in Sohag, Egypt in 1984. He received B.Sc and M.Sc from electrical engineering, Assiut university in 2006 and 2012 respectively. He is employing by the Electrical Engineering Dept. of Assiut University, Egypt as professor assistant, researcher. Currently he is a PhD student in Ural Federal University, Russia. His research interests include stability and reliability of renewable sources connected to electrical power systems. E-mail: mahmoud2006aref@gmail.com.

Ismaiel A. I. Ahmed, was born in Sohag, Egypt in 1988. He received B.Sc from electrical engineering, Assiut university in 2010. Currently he works in transformers factory in Russia. His research interests include stability and reliability of renewable sources connected to electrical power systems. E-mail: en.ismaiel@gmail.com

Vladislav P. Oboskalov, graduated from UPI (Yekaterinburg) in 1963, received the qualification of electrical engineer. Received the degree of Candidate of Technical Sciences in 1970, doctor of Technical Sciences in 1999. Professor since 2000. Currently is working in the Automated Electric Systems Department of Ural Federal University. His research interest include Reliability, optimization, operation and economics of electric power systems. E-mail: vpo1704 @mail.ru 